\title{
Alergia ao Látex: Diagnóstico Acidental após Procedimento Urológico. Relato de Caso *
}

\section{Latex Allergy: Accidental Diagnosis after Urological Procedure. Case Report}

\author{
Bruno Araújo Verdolin ${ }^{1}$; Walkíria Wingester Villas Boas, TSA $^{2}$; Renato Santiago Gomez, TSA ${ }^{3}$
}

\section{RESUMO}

Verdolin BA, Villas Boas WW, Gomez RS - Alergia ao Látex: Diagnóstico Acidental após Procedimento Urológico. Relato de Caso

JUSTIFICATIVA E OBJETIVOS: A alergia aos produtos derivados do látex tem-se tornado um problema de grandes proporções, afetando tanto os pacientes como os profissionais da saúde. O objetivo deste relato é descrever o diagnóstico acidental de alergia ao látex após uma cirurgia urológica sob raquianestesia em que o paciente apresentou quadro clínico compatível ao choque anafilático.

RELATO DO CASO: Paciente do sexo masculino, 16 anos, portador de lesão de uretra posterior e em uso de sonda vesical por 3 anos, devido a duas cirurgias prévias sem sucesso. Durante o procedimento cirúrgico sob raquianestesia com bupivacaína, o paciente apresentou, logo após a exploração da cavidade abdominal, confusão, dispnéia, prurido e eritema generalizado, broncoespasmo, hipotensão arterial e taquicardia. Houve melhora gradativa das alterações apresentadas com o tratamento instituído. Durante a permanência no hospital, o paciente apresentou, ao soprar um balão de festa, urticária de contato na face e broncoespasmo, que foram prontamente tratados. O teste de punção cutânea e a dosagem de IgE especifica para o látex confirmaram a hipótese diagnóstica de alergia ao látex.

CONCLUSÕES: A combinação da história clínica do paciente com os dados laboratoriais permitiram a identificação do quadro de alergia ao látex. Esta entidade vem apresentando grande importância recentemente, principalmente naqueles pacientes de risco, como é o do presente caso.

Unitermos: ANESTÉSICOS, Local: bupivacaína; COMPLICAÇÕES, Alergia: látex; TÉCNICAS ANESTÉSICAS, Regional: subaracnóidea

\footnotetext{
* Recebido do (Received from) CET/SBA do Hospital das Clínicas da Faculdade de Medicina da Universidade Federal de Minas Gerais (UFMG)

1. Anestesiologista do Hospital das Clínicas da Universidade Federal de Minas Gerais (UFMG); Mestre em Bioquímica-Imunologia pela UFMG

2. Co-responsável pelo CET/SBA do Hospital das Clínicas da Faculdade de Medicina da UFMG; Mestre em Fisiologia pela UFMG

3. Professor Adjunto do Departamento de Cirurgia da Faculdade de Medicina da UFMG; Mestrado e Doutorado em Farmacologia pela UFMG; Responsável pelo CET/SBA do Hospital das Clínicas da Faculdade de Medicina da UFMG
}

Endereço para Correspondência (Correspondence to) Dr. Renato Santiago Gomez

Dept ${ }^{\circ}$ de Cirurgia, Sala 4000

Av. Alfredo Balena, 190

30130-100 Belo Horizonte, MG

E-mail: renatogomez@ig.com.br

Apresentado (Submitted) em 30 de setembro de 2002

Aceito (Accepted) para publicação em 06 de janeiro de 2003

(C) Sociedade Brasileira de Anestesiologia, 2003

\section{SUMMARY}

Verdolin BA, Villas Boas WW, Gomez RS - Latex Allergy: Accidental Diagnosis after Urological Procedure. Case Report

BACKGROUND AND OBJECTIVES: Allergy to natural rubber latex products has become a major source of concern, affecting both patients and healthcare workers. This report aimed at describing an accidental diagnosis of latex allergy after urological surgery under spinal anesthesia when patient presented clinical manifestations of anaphylactic shock.

CASE REPORT: Male patient, 16 years old, with posterior urethra lesion who had been managed for the last 3 years with chronic indwelling latex urethral catheter due to two previous unsuccessful attempts to restore urinary drainage. During surgery under spinal anesthesia, patient presented soon after peritoneal cavity exploration, confusion, dyspnea, generalized pruritus and erythema, bronchospasm, arterial hypotension and tachycardia. Clinical manifestations faded gradually after treatment. During hospital stay and after blowing a toy balloon, patient developed contact hives on the face and bronchospasm, which were promptly treated. Prick and serologic test for latex-specific IgE have confirmed the diagnostic hypothesis of latex allergy.

CONCLUSIONS: The combination of patient's clinical history and lab findings have allowed for the identification of latex allergy. This entity is becoming highly relevant, especially for risk patients, as in this case report.

Key Words: ANESTHETICS, Local: bupivacaine; ANESTHETIC TECHNIQUES, Regional: spinal block; COMPLICATIONS, Allergy: latex

\section{INTRODUÇÃO}

látex é um derivado natural da seringueira (Hevea brasiliensis) e, embora a introdução das luvas cirúrgicas contendo látex tenha ocorrido em 1890, somente em 1979 é que a alergia a este produto foi reconhecida como um problema médico ${ }^{1}$. Posteriormente, ocorreu um aumento substancial no número de relatos de alergia ao látex. Os profissionais da área de saúde apresentam um risco em particular. Alguns pacientes representam um grupo de risco para a ocorrência de reações anafiláticas inesperadas durante a cirurgia. Entre estes pacientes pode-se destacar, principalmente, crianças com espinha bífida ou anormalidades do trato genito-urinário, que adquirem hipersensibilidade ao látex, como resultado de sondagem vesical de repetição e múltiplos procedimentos cirúrgicos prévios $^{2-4}$.

O objetivo deste relato é apresentar o caso de um paciente, em que o diagnóstico fortuito de alergia ao látex foi obtido após uma cirurgia urológica sob raquianestesia, em que o paciente apresentou quadro clínico compatível ao choque anafilático. 


\section{RELATO DO CASO}

Paciente do sexo masculino, 16 anos, com lesão de uretra posterior e que, durante os últimos três anos, esteve em uso contínuo de cateter vesical em decorrência de duas cirurgias prévias, sem sucesso, para restauração da drenagem urinária. Após avaliação urológica, foi decidida a realização de uma nova intervenção cirúrgica. O paciente não apresentava história de alergia e não fazia uso de medicações. Os resultados dos exames laboratoriais eram normais. O paciente não recebeu medicação pré-anestésica na noite anterior à cirurgia. Foi realizada raquianestesia com agulha $25 \mathrm{G}$, utilizando-se bupivacaína a $0,5 \%$ hiperbárica $(20 \mathrm{mg})$. A monitorização consistiu em oximetria de pulso $\left(\mathrm{SpO}_{2}\right)$, pressão arterial não invasiva, eletrocardiografia (ECG), e medida do débito urinário com cateter uretral de látex após a instalação do bloqueio em nível sensitivo satisfatório (T6). Poucos minutos após a exploração da cavidade peritoneal, o paciente, subitamente, tornou-se confuso, dispnéico, e, apresentou prurido intenso generalizado seguido por eritema. Em seguida, o paciente apresentou hipotensão arterial, taquicardia, broncoespasmo e diminuição da saturação de oxigênio. Inicialmente foi realizada ventilação assistida por máscara; porém, como não houve melhora da ventilação, foi realizada intubação traqueal. Foram administrados salbutamol por via inalatória e aminofilina (120 mg) por via venosa para o controle do broncoespasmo. Hidratação venosa (2 litros de solução fisiológica a $0,9 \%$ ) e efedrina (30 $\mathrm{mg}$ ) por via venosa foram necessárias para restaurar a pressão arterial. Como a hipótese diagnóstica foi de choque anafilático, foram administrados $500 \mathrm{mg}$ de metilprednisolona. Após as medidas terapêuticas, a pressão arterial, a freqüência cardíaca e a ventilação foram gradativamente retornando aos valores iniciais. O eritema persistiu por cinco horas e cedeu gradualmente.

O paciente permaneceu no hospital por três semanas, devido à pneumonia e, após soprar um balão de festa durante uma comemoração no hospital, apresentou eritema, edema e prurido na face e broncoespasmo, que foi prontamente tratado. Devido à suspeita diagnóstica de alergia ao látex, foi solicitada a realização do teste de punção cutânea (prick test) e teste sorológico para dosagem de IgE específica para o látex através do ensaio radioalergoaborvente (RAST). No teste de punção cutânea, uma resposta positiva (3+ em uma escala de 1 a 4) foi obtida com extratos de luva cirúrgica. Adosagem de IgE específica para látex foi de 17,5 UI/ml, que é considerada altamente positiva (classe 4: muito alto).

\section{DISCUSSÃo}

O látex representa uma mistura complexa de proteínas hidrossolúveis extraídas da seringueira e está presente em muitos produtos como as luvas cirúrgicas, sondas, catéteres, como também em vários produtos médicos e não-médi$\cos ^{5}$. A alergia ao látex tem-se tornado uma ocorrência de grande preocupação na prática médica. A síndrome clínica de sensibilidade aos produtos contendo látex manifesta-se tanto por reação de Gell-Coombs do tipo IV (hipersensibili- dade retardada) ou do tipo I (hipersensibilidade imediata) ${ }^{6,7}$ As reações do tipo IV são mediadas pelos linfócitos T, localizam-se na área de contato (dermatite de contato), sendo decorrentes da sensibilização através da pele. Estas reações são de início lento (24 a 48 horas) e caracterizam-se por secura, prurido, eritema e edema, podendo evoluir para eczema, pápulas e ulcerações. Tem sido sugerido por alguns investigadores que as lesões abertas da pele podem predispor à sensibilização de $\operatorname{lgE}{ }^{8-10}$. Esta reação ocorre, mais freqüentemente, em resposta à presença dos aditivos (tetrametiltiourano e mercaptobenzotiazol) utilizados no processo de manufatura da borracha ${ }^{7,10}$. Estima-se que aproximadamente $7 \%$ dos trabalhadores em saúde apresentam dermatite de contato eczematosa ${ }^{10}$.

Por outro lado, a reação do tipo I é uma hipersensibilidade mediada por $\lg \mathrm{E}$ às proteínas retidas nos produtos finais do látex ${ }^{9-12}$. Esta reação de hipersensibilidade é imediata: leva apenas alguns minutos para se manifestar e é mais grave. Nesta reação ocorre desgranulação dos mastócitos com a liberação de histamina e outros mediadores como leucotrienos e prostaglandinas. Um amplo espectro de manifestações clínicas variando de urticária de contato, rinoconjuntivite, crise asmática até anafilaxia grave, incluindo morte, tem sido associado a hipersensibilidade do tipo I ao látex ${ }^{9-12}$. A urticária de contato ocorre, em geral, 5 a 60 minutos após o contato cutâneo e caracteriza-se por eritema, prurido, eczema, edema, podendo evoluir para reações generalizadas mais graves (broncoespasmo, choque anafilático).

Crianças com espinha bífida e anormalidades urológicas congênitas apresentam um risco aumentado de adquirir alergia ao látex com uma prevalência de $20 \%$ a $65 \%{ }^{3,4,13}$. É sugerido que este risco aumentado seja resultante da exposição crônica aos produtos contendo látex (sonda vesical de demora) e as freqüentes cirurgias a que estes pacientes são normalmente submetidos ${ }^{2-4}$. Trinta e dois por cento dos pacientes com espinha bífida apresentam teste de punção cutânea positivo para o látex, indicando a presença de IgE específica para o látex ${ }^{2,12,13}$.

Reações sistêmicas ao látex podem resultar da exposição às proteínas do látex por diversas vias, tais como a pele, a mucosa, a inalatória, a venosa e através dos tecidos internos. Reações graves foram relatadas em decorrência do uso de tubos traqueais e equipamentos de anestesia, como também do talco presente nas luvas cirúrgicas ${ }^{14-16}$. Um grande número de casos na literatura descrevem reações alérgicas graves do tipo anafilática, relacionadas ao contato da luva cirúrgica com o peritônio e as vísceras, uma vez que estes tecidos absorvem prontamente as proteínas do látex contidas nas luvas cirúrgicas. A via venosa também tem sido implicada, devido à presença de látex nos êmbolos das seringas e nos frascos de medicações ${ }^{17}$. No presente caso, os primeiros sinais de anafilaxia ocorreram logo após a penetração da cavidade abdominal e manipulação das alças intestinais e vísceras. Portanto, parece ter sido esta a via pela qual ocorreu o contato do paciente com o látex, desencadeando toda a sintomatologia apresentada durante a cirurgia. Entretanto, como o cateter uretral utilizado era de látex, não podemos 
afastar a possibilidade da participação do mesmo como responsável pelo desencadeamento do quadro clínico, reforçando a necessidade da utilização preferencial de material não contendo látex (silicone, por exemplo) com o intuito de se evitar a sensibilização destes pacientes ao longo dos anos. Da mesma forma, podemos inferir que o paciente apresentou quadro clínico compatível com urticária de contato ao látex, após o contato com o balão de festa. A hipótese diagnóstica de alergia ao látex foi então formulada como a responsável pelo choque anafilático apresentado pelo paciente durante a cirurgia. Amesma foi confirmada através da utilização do teste de punção cutânea e da dosagem de IgE específica para o látex.

Os testes para determinar a hipersensibilidade ao látex têm sido questionados devido à baixa precisão e segurança. Os testes de punção cutânea ou intradérmicos são difíceis de padronizar quanto ao antígeno. Recomenda-se a realização do teste de punção cutânea, utilizando-se extratos obtidos de duas fontes comerciais diferentes ou, quando disponível, o extrato padronizado de látex (Stallergenes $\left.{ }^{\circledR}\right)^{18}$. Tem sido relatado anafilaxia causada pelos testes cutâneos. Assim, recomenda-se sua utilização em ambiente hospitalar onde estão presentes os recursos de monitorização e reanimação. O teste de ELISA e o teste radioalergoabsorvente (RAST) para detecção de lgE específica para o látex têm sensibilidade em torno de $50 \%$ a $70 \%$, apresentando menor sensibilidade que o teste de punção cutânea ${ }^{2,11}$. Esses testes não distinguem pacientes com probabilidade de ter reações localizadas daqueles em risco de episódios graves. O início de um quadro de anafilaxia durante a cirurgia ou procedimentos médicos é a forma de apresentação clínica mais alarmante. Freqüentemente é difícil identificar o agente envolvido e excluir a participação das drogas anestésicas. Entretanto, a alergia ao látex deve ser considerada no diagnóstico diferencial de anafilaxia per-operatória especialmente em pacientes de grupo de risco. A principal consideração a ser feita em relação ao presente caso é que não foi feita avaliação pós-operatória para se identificar o agente responsável pelo choque anafilático. Somente após o aparecimento da urticária de contato é que a hipótese de alergia ao látex foi levada em consideração e a investigação específica foi solicitada. Isto reforça o fato de que os profissionais da área de saúde devam estar familiarizados com esta entidade, principalmente pela abundância de produtos de látex nas salas de operações. É imperativo que os anestesiologistas estejam preparados para diminuir a exposição ao látex durante a anestesia no paciente sensibilizado.

Concluindo, a alergia ao látex está emergindo como um sério problema de saúde pública em diversos tipos de pacientes. A comunidade médica, em especial a Anestesiologia, a cirurgia e a enfermagem devem estar cientes dessa condição que pode colocar em risco a vida do paciente.

\section{Latex Allergy: Accidental Diagnosis after Urological Procedure. Case Report}

Bruno Araújo Verdolin, M.D., Walkíria Wingester Villas Boas, TSA, M.D., Renato Santiago Gomez, TSA, M.D.

\section{INTRODUCTION}

Latex is a natural rubber tree (Hevea brasiliensis) byproduct and, although latex-containing surgical gloves were introduced in 1890, it was only in 1979 that the allergy for such product was recognized as a medical problem ${ }^{1}$. This was followed by a major increase in the number of latex allergy reports. Health professionals are at special risk. Some patients represent a risk group for unexpected anaphylactic reactions during surgery. Among those patients, one may especially highlight children with spina bifida or genitourinary tract disorders, who develop hypersensitivity to latex as result of repeated vesical catheters and multiple surgical procedures $^{2-4}$

This report aimed at describing an accidental diagnosis of latex allergy after urological surgery under spinal anesthesia when patient had clinical evidences of anaphylactic shock.

\section{CASE REPORT}

Male patient, 16 years old, with posterior urethra lesion who had been managed for the last 3 years with chronic indwelling latex urethral catheter due to two previous unsuccessful attempts to restore urinary drainage. A new surgical intervention was recommended after urological evaluation. Patient had no previous allergy history and was not under any medication. Lab results were normal. Patient was not premedicated the evening before surgery. Spinal anesthesia was induced with $0.5 \%$ hyperbaric bupivacaine $(20 \mathrm{mg})$ injected through a $25 \mathrm{G}$ needle. Monitoring consisted of pulse oximetry $\left(\mathrm{SpO}_{2}\right)$, non-invasive blood pressure, ECG and urinary output measured through a urinary latex catheter after blockade installation in a satisfactory level (T6). Few minutes after abdominal cavity exploration, patient suddenly presented with confusion, dyspnea and severe generalized pruritus followed by erythema. Next, patient presented arterial hypotension, tachycardia, bronchospasm and decreased oxygen saturation. Initial treatment was assisted ventilation under mask, but since there was no ventilation improvement, patient was intubated. Inhalational salbutamol and intravenous aminophyline $(120 \mathrm{mg})$ were administered to control bronchospasm. Intravenous hydration ( 2 liters $0.9 \%$ saline solution) and ephedrine $(30 \mathrm{mg})$ were needed to restore blood pressure. Since the diagnostic hypothesis was anaphylactic shock, $500 \mathrm{mg}$ methylprednisolone were administered. After treatment, blood pressure, heart rate and ventilation gradually returned to baseline values. Erythema persisted for 5 hours and gradually improved.

Patient remained in the hospital for 3 weeks due to pneumonia and after blowing a toy balloon during a celebration in the 
hospital, presented with erythema, edema and pruritus on the face, and bronchspasm, which was promptly treated. Due to diagnostic suspicion of latex allergy, prick test and serological test for latex-specific IgE via radioallergoabsorbent essay (RAST) were requested. A positive response to prick test ( $3+$ in a scale of 1 to 4 ) was obtained with surgical glove extracts. Latex-specific IgE dosage was $17.5 \mathrm{Ul} / \mathrm{ml}$, considered highly positive (class 4 : very high).

\section{DISCUSSION}

Latex is a complex blend of hydrosoluble proteins extracted from the rubber tree and is present in several products such as surgical gloves, probes and catheters, as well as in other medical and non-medical products ${ }^{5}$. Latex allergy is becoming of great concern for the clinical practice. Clinical syndrome of sensitivity to latex-containing products is manifested both by Gell-Coombs reaction type IV (late hypersensitivity) and type I (immediate hypersensitivity) ${ }^{6,7}$. Reactions type IV are mediated by T lymphocytes, are located in the contact area (contact dermatitis) and are caused by sensitization through the skin. These are late reactions (24 to 48 hours) and are characterized by dryness, pruritus, erythema and edema, which may progress to eczema, papulae and ulcerations. Some investigators have suggested that open skin injuries may predispose to IgE sensitization ${ }^{8-10}$. This reaction is more commonly a response to the presence of additives (tetramethylthiourane and mercaptobenzothiazol) used in rubber manufacturing ${ }^{7,10}$. It is estimated that approximately $7 \%$ of health professionals have eczematous contact dermatitis ${ }^{10}$.

On the other hand, reaction type I is an IgE-mediated hypersensitivity to proteins trapped in finished latex products ${ }^{9-12}$. This is an immediate reaction taking only a few minutes to be present and being more severe. There is mast cells degranulation with histamine and other mediators release, such as leucotriens and prostaglandins. A wide range of clinical manifestations, from contact hives, rhinoconjuntivitis and asthma crisis to severe anaphylaxis, including death, have been associated to latex hypersensitivity type $\mathrm{I}^{9-12}$. Contact hives is in general present 5 to 60 minutes after skin exposure, is characterized by erythema, pruritus, eczema and edema, and may progress to more severe generalized reactions (bronchospasm, anaphylactic shock).

Spina bifida children or those with congenital urological disorders are at increased risk for latex allergy with an incidence of $20 \%$ to $65 \%^{3,4,13}$. It has been suggested that this increased risk is a consequence of chronic exposure to latex-containing products (indwelling vesical catheter) and frequent surgeries to which such patients are in general submitted ${ }^{2-4}$. Positive prick test for latex is found in $32 \%$ of spina bifida patients, indicating the presence of latex-specific $\lg \mathrm{E}^{2,12,13}$.

Systemic reactions to latex may result from the exposure to latex proteins by several ways, such as cutaneous, mucosal, inhalational, intravenous and through internal tissues. Severe reactions were reported as a consequence of tracheal tubes and anesthesia equipment as well as of the talcum powder of surgical gloves ${ }^{14-16}$. A large number of reports describe severe anaphylactic-type allergic reactions related to the contact of the surgical glove with the peritoneum and viscerae, since those tissues promptly absorb latex proteins of surgical gloves. The intravenous route has also been implied due to the presence of latex in syringe plungers and drug vials ${ }^{17}$. In our case, the first signs of anaphylaxis appeared soon after abdominal cavity penetration and manipulation of intestinal loops and viscerae. So, this seems to be the route through which patient got in contact with latex, triggering all the symptoms presented during surgery. However, since the urethral catheter used was made of latex, we cannot rule out the possibility of its participation in triggering symptoms, reinforcing the need for preferring non latex-containing materials (silicone, for example), aiming at avoiding the sensitization of those patients along the years. Similarly, one may infer that the patient had clinical symptoms compatible with latex contact hives, after contact with the toy balloon. The diagnostic hypothesis of latex allergy was then formulated as responsible for the anaphylactic shock presented by the patient during surgery. This was confirmed by prick test and latex-specific IgE dosage.

Tests to determine latex hypersensitivity have been questioned due to the low level of accuracy and safety. Prick or intradermal tests are difficult to standardize in terms of antigens. Prick test is recommended with extracts obtained from two different commercial sources or, when available, with standardized latex extract (Stallergenes ${ }^{\circledR}$ ) ${ }^{18}$. Anaphylaxis triggered by skin-tests has been reported. So, the recommendation is to use it in the hospital where monitoring and resuscitation tools are available. ELISA test and radioallergoabsorbent (RAST) test for detecting latex-specific IgE have approximately $50 \%$ to $70 \%$ sensitivity being less sensitive than prick tests ${ }^{2,11}$. These tests do not differ patients likely to have localized reactions from those at risk for severe episodes.

The beginning of anaphylaxis during surgery or medical procedures is the most alarming clinical manifestation. In general, it is difficult to identify the agent involved and rule out the participation of anesthetic drugs. Latex allergy, however, should be considered in the final diagnosis of perioperative anaphylaxis, especially in risk patients. The primary consideration in our case is that no postoperative evaluation was performed to identify the agent responsible for the anaphylactic shock. Only after contact hives is that the hypothesis of latex allergy was taken into consideration and the specific investigation was requested. This reinforce the fact that health professionals should be familiar with this entity, especially due to the abundance of latex products in the operating room. It is mandatory that anesthesiologists be prepared to decrease latex exposure during anesthesia of sensitized patients.

In conclusion, latex allergy is emerging as a severe public health problem in different patients. The medical community, especially Anesthesiology, surgery and nursing, should be aware of this condition which may be life-threatening. 


\section{REFERÊNCIAS - REFERENCES}

01. Nutter AF - Contact urticaria to rubber. Br J Dermatol, 1979; 191:597-598.

02. Moneret-Vautrin DA, Beaudouin E, Widmer S et al - Prospective study of risk factors in natural rubber hypersensitivity. J Allergy Clin Immunol, 1993;92:668-677.

03. Beaudouin E, Prestat F, Schmitt M et al - High risk of sensitization to latex in children with spina bifida. Eur J Pediatr Surg 1994;4:90-93.

04. Niggemann B, Breiteneder H - Latex allergy in children. Int Arch Allergy Immunol, 2000;121:98-107.

05. Mertes PM, Laxenaire MC - Allergic reactions occurring during anaesthesia. Eur J Anaesth, 2002;19:240-262

06. Boxer MB - The dangers of latex allergy. Emerg Med, 1993;25:18-26.

07. Slater JE - Allergic reactions to natural rubber. Ann Allergy, 1992;68:203-209.

08. Fisher AA - Allergic contact reactions in health personnel. J Allergy Clin Immunol, 1992;90:729-738.

09. Sussman G, Tarlo S, Dolovich J - The spectrum of IgE-mediated responses to latex. JAMA, 1991;265:2844-2847.

10. Kam PCA, Lee MSM, Thompson JF - Latex allergy: an emerging clinical and occupational health problem. Anaesthesia, 1997;52:570-575.

11. Holzman RS - Latex allergy: an emerging operating room problem. Anesth Analg, 1993;76:635-641.

12. Steelman VM - Latex allergy precautions: a research based protocol. Nurs Clin North Am, 1995;30:475-493.

13. Slater JE, Mostello LA, Shauer C - Rubber specific IgE in children with spina bifida. J Urol, 1991;146:578-579.

14. Gerber AC, Jorg W, Zbinden S et al - Severe intraoperative anaphylaxis to surgical gloves: latex allergy, an unfamiliar condition. Anesthesiology, 1989;71:800-802.

15. McKinstry LJ, Fenton WJ, Barrey P - Anaesthesia and the patient with latex allergy. Can J Anaesth, 1992;39:587-589.

16. Beezhold DH, Beck WC - Surgical gloves powders bind latex antigens. Arch Surg, 1992;127:1354-1357.

17. Kearns CF, Norris A - Latex allergy and plastic syringes. Anesth Analg, 1996;82:429.

18. Turjanmaa K, Palosuo T, Alenius $\mathrm{H}$ et al - Latex allergy diagnosis: in vivo and in vitro standardization of a natural rubber latex extract. Allergy, 1992;52:41-50.

\section{RESUMEN}

Verdolin BA, Villas Boas WW, Gomez RS - Alergia al Látex: Diagnóstico Accidental después Procedimiento Urológico. Relato de Caso

JUSTIFICATIVA Y OBJETIVOS: La alergia a los productos derivados del látex se han convertido en un problema de grandes proporciones, afectando tanto los pacientes como también, los profesionales de la salud. El objetivo de este relato es describir el diagnóstico accidental de alergia al látex después de una cirugía urológica sobre raquianestesia en que el paciente presentó cuadro clínico compatible con choque anafilático.

RELATO DE CASO: Paciente del sexo masculino, 16 años, portador de lesión de uretra posterior y en uso de sonda vesical por 3 años debido a dos cirugías previas sin suceso. Durante el procedimiento quirúrgico sobre raquianestesia con bupivacaína el paciente presentó, luego después de la exploración de la cavidad abdominal, confusión, dispnéia, prurido y eritema generalizado, broncoespasmo, hipotensión arterial y taquicardia. Hubo mejora gradativa de las alteraciones presentadas con el tratamiento establecido. Durante la permanencia en el hospital el paciente presentó, al soplar un balón de fiesta, urticaria de contacto en la face y broncoespasmo, que fueron prontamente tratados. La prueba de punción cutánea y la dosificación de IgE específica para el látex confirmaran la hipótesis diagnóstica de alergia al látex.

CONCLUSIONES: La combinación de la historia clínica del paciente con los datos laboratoriales permitieron la identificación del cuadro de alergia al látex. Esta entidad viene presentando grande importancia recientemente, principalmente en aquellos pacientes de riesgo, como es el del presente caso. 